\title{
THE SIGNIFICANCE OF CONTROLLING IN ENTERPRISES IN EMERGING ECONOMIES
}

\section{Sedliačiková, M., Moresová, M., Drábek, J., Kupčák, V.}

Mariana Sedliačiková / Technical University of Zvolen, Faculty of Wood Sciences and Technology, Department of Business Economics, T. G. Masaryka 24, 96001 Zvolen, Slovakia. Email: sedliacikova@tuzvo.sk

Maria Moresová / Technical University of Zvolen, Faculty of Wood Sciences and Technology, Department of Business Economics, T. G. Masaryka 24, 96001 Zvolen, Slovakia. Email: maria.moresova@tuzvo.sk

Josef Drábek / Technical University of Zvolen, Faculty of Wood Sciences and Technology, Department of Business Economics, T. G. Masaryka 24, 96001 Zvolen, Slovakia. Email: drabek@tuzvo.sk

Václav Kupčák / Mendel University in Brno, Faculty of Forestry and Wood Technology, Department of Forest and Wood Products Economics and Policy, Zemědělská 3, 61300 Brno, Czech Republic. Email: kupcak@mendelu.cz

\section{Abstract}

Globalisation and increasing competition affect all existing enterprises, as well as those in emerging economies. For this reason, enterprises continuously improve their own management systems and try to gain a competitive advantage in the market in addition to eliminating shortcomings. In emerging economies in Central Europe, including Slovakia, there are still not well-established tools to support management decisions that could reveal reserves, identify deviations from the required state and reflect all these attributes in the system of motivation, evaluation, and remuneration of employees. Controlling is such a tool, the implementation of which is a prerequisite for growth in performance and market value of the enterprise. The aim of the paper is to identify and present the optimal software support for controlling for the given segment of enterprises based on the mapping of the current state of using Business Intelligence to support controlling in micro and small enterprises (MSEs) in the conditions of the specific emerging economy, namely Slovakia. This information system will allow MSEs to respond flexibly to market changes, offer alternative options to support managerial decisions and can simulate the impact of any change in the plan on business management. Within empirical research, a questionnaire was used as a method to survey the given problem in the business practice of micro and small enterprises in Slovakia. The questionnaire was sent to 2,415 MSEs, with the research sample consisting of 421 respondents, i.e. of $17.43 \%$. The survey meets the condition of a minimum sample size. We focused on groups of micro and small enterprises, as these represent $99 \%$ of the country's market potential. While the introduction of the controlling module into the basic information systems of the company or Business Intelligence are investment-intensive for MSEs, as a real option, affordable software support for controlling based on the MS Excel programme was identified in practice. In view of the above, a prototype of a controlling information system called 'SOFIN-KA' was designed and successfully tested in the practice of the Slovak Republic in an MS Excel programme, which is customisable to each MSEs. 
Implications for Central European audience: For the success of micro and small enterprises (MSEs) in today's turbulent business environment, it is important to make better and faster decisions. However, MSEs in Central Europe, including Slovakia, currently do not often have sufficiently established tools to support management decisions. One of the ways to solve this problem is controlling. The proposed software support for controlling is applicable not only in Slovak MSEs but also in V4 countries. The software has been designed this way that it can always be adapted to the specific conditions of each company.

Keywords: business intelligence; emerging economies; controlling; globalisation; MS Excel JEL Classification: M12, M21, M29

\section{Introduction}

Globalisation, as agreed by Peréz-Nordtvedt et al. (2008), Deming (2017) and Marceta \& Bojnec (2020), is currently considered a key factor in the further development of the world economy. At the same time, it provokes considerable discussions in theoretical and governmental circles as well as in society. Globalisation in business is characterised mainly by the growing range of cross-border economic activities, i.e. penetration of competition into domestic markets and opening of foreign markets, international acquisitions, strategic alliances, as well as their impact on industrial restructuring. Globalisation presents an unprecedented increase in competition at both the micro and macro levels. Emerging economies have also had to engage in the process of globalisation and adapt their business strategy in this direction. The last two decades, as reported by Ratinger et al. (2020), Vrchota et al. (2020) and Jerman et al. (2020), in the development of the economies of developing countries, were characterised by improving and building mainly distribution systems in the context of expanding international trade. The main emerging economies include Brazil, China, India, Russia, and South Africa. In the case of Central Europe, a significant example of an emerging economy in the Slovak Republic, in which micro and small enterprises (MSEs), as in developed EU countries, form a crucial part of the country's economic potential. In the Slovak Republic, approximately $93 \%$ of all business entities are micro-enterprises (09 employees), $6 \%$ are small enterprises (10-49 employees), $0.8 \%$ are medium-sized enterprises (50-249 employees), and only $0.2 \%$ are large enterprises (with more than 250 employees). MSEs significantly participate in creating added value, providing jobs, while their progress and success create new job opportunities and strengthen the economy (SBA Fact Sheet Slovakia, 2018).

For the success of MSEs in today's turbulent business environment, it is important to make better and faster decisions, which means to operate more efficiently, increase its competitiveness and further develop. Micro and small business managers need to be able to handle the flow of information, process it, analyse, make output and, based on it, make the right decisions. It results from the above that new management requirements are imposed on MSEs. However, MSEs in emerging economies, including Slovakia, currently do not often have sufficiently established tools to support management decisions that would be able to reveal reserves, identify deviations from the required state, the causes of their occurrence, assign them to individual departments based on the principle of responsibility for their origin and then reflect them in the system of motivation, evaluation, and remuneration of employees. 
One of the ways to solve this problem is controlling, which is an effective tool for active management of the future of the company, which aims to provide real information in real-time to increase the performance and financial health of the company (Bernardová et al., 2020; Dvorský et al., 2020; Lesnikova \& Schmidtova, 2020; Hitka et al., 2014; Stroková \& Drábek, 2018; Vetráková et al., 2018). At present, it is not possible to implement controlling without adequate software support. Business intelligence presents software that aims to acquire, process, analyse and present data. It serves to support decision-making and planning in business. The term Business Intelligence was first defined in 1989. Nevertheless, the rapid development occurred later, and it was evident before the onset of the economic crisis. In Slovakia, information systems of the ERP (enterprise resource planning) type, which can be considered as the predecessors of information systems (IS) of the Business Intelligence type, are still very popular at present. Their role is to integrate, automate and manage various areas of business from production, logistics, sales, asset management, customer relations to invoicing and accounting (Chaudhuri et al., 2011). The above facts have led us to write this paper. The aim of the paper is to map the current state of use of Business Intelligence to support controlling in micro and small enterprises in the conditions of a particular emerging economy, Slovakia, as well as to identify and present the optimal software support for controlling for a given segment of enterprises. Such an information system will allow MSEs to respond flexibly to market changes, offer alternative options for management decisions, and be able to simulate the impact of any change in the plan on the economy and performance of the enterprise.

\section{Literature review}

The term 'controlling' got into European terminology from the USA, where it first appeared in economic theory and practice at the end of the 19th century. The word base is the term 'to control'. In practice, more than 50 different meanings of the term have been found, in the sense of to lead, manage, regulate, govern, administer, supervise, rule over (Potkány \& Babiaková, 2013). It means that to understand controlling only in the meaning of the 'control' (as it often happens) would be a significant restriction of the real content of this term, as it would only be control of business activities. Controlling is an effective tool for active management of the company's future, which connects management and information subsystems (planning, control, budgeting, calculations, accounting, statistics, other forms of records and reporting, etc.). Its task is to provide information for the business management, preparation of documents for setting the goals of the company and planning, monitoring the implementation of the plan, detecting deviations, their analysis and proposal of corrective measures (Sedliačiková et al., 2012; Šatanová \& Sedliačiková, 2014). The aim of controlling is not to replace the work of the manager, but information support in planning and setting business goals, continuous acquisition and processing of information to support decisionmaking, creating methodological procedures to support managerial decisions, designing alternative solutions, simulating their impacts, supporting control with emphasis on analysis of deviations, processing information into reports and overviews, preparation of forecasts (forecast, estimate) and proposing corrective measures. It means that the functions of controlling are advisory, information, innovation, coordination and checking, but not control (Sedliačiková, 2013).

In current business-economic theory, several approaches define the structure of controlling in the company (Claussen, 2003; Fischer et al., 2012; Foltínová, 1997; Fickert et al., 2003; 
Krause \& Dayanand, 2010; Šatanová \& Sedliačiková, 2014). The limitation of these approaches is that they are designed regardless of the size of the enterprise. After the analysis of several approaches, as well as based on our own empirical research in practice (Sedliačiková et al., 2019), the concept of controlling structure for small and medium-sized enterprises (SMEs) was proposed (Hajdúchová et al., 2017; Šatanová \& Sedliačiková, 2014; Szalavetz, 2019). In terms of the dimension of time, it is possible to divide controlling into strategic and operational. In this approach, operational controlling is divided into financial, cost, investment, personnel controlling and quality controlling.

\section{Figure $1 \mathrm{I}$ Controlling structure in SMEs}

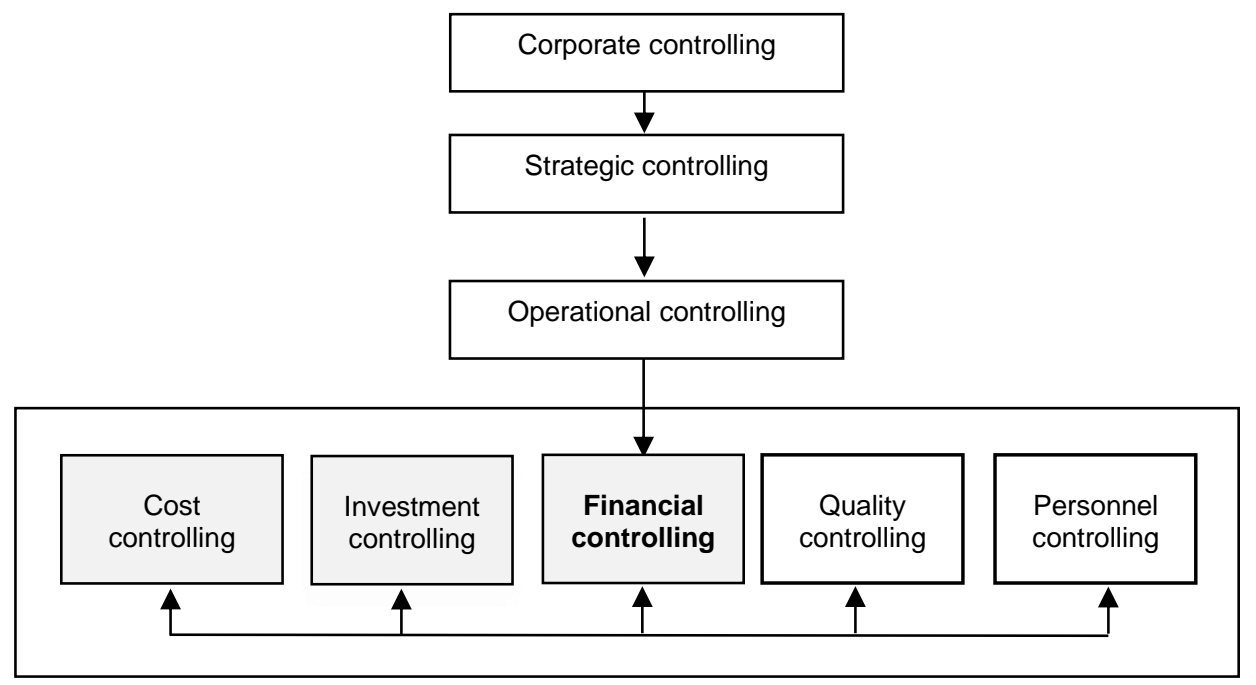

Source: Sedliačiková et al. (2019)

Cost, financial and investment controlling are crucial subsystems in terms of the possibilities of applying controlling in SMEs. According to several authors, financial controlling plays a key role, which is the core of controlling in SMEs, because it has an integrating function (Stroková \& Drábek, 2018).

Strategic controlling is typical for its future orientation. It has a medium to long-term character. It systematically monitors future opportunities and threats (Potkány \& Babiaková, 2013; Šatanová \& Sedliačiková, 2014). Operational controlling is oriented toward the present or short-term future. It deals mainly with information obtained at present or in the past. Opportunities and threats are transformed into costs, revenues, expenses, and incomes. The essence of operational controlling is to formulate a management system of profit, cover contribution and cash flow (Šatanová \& Sedliačiková, 2014). The aim of financial controlling is to solve the problems of financial balance (liquidity) of the company at any moment while considering the goals of profitability (Sedliacikova et al., 2015). The central task of financial controlling is to support the management of funds needed to cover payments incurred in the corporate transformation process (Sedliačiková et al., 2016). Cost controlling (in-corporate, profit) is focused on the issue of cost, revenue, and profit management. It is mainly economic (value) management, the essence of which lies in the calculation and cost system, which is customised to each company. Its task is to solve the problems of cost analysis, calculation 
methods and procedures (using the calculation of incomplete costs, which is based on the principle of addressability, not on the principle of averaging), cost budgets, pricing methodology and monitoring deviations from the plan based on flexible budget (Šatanová \& Sedliačiková, 2014). Investment controlling is focused on the detection and assessment of investment opportunities, project planning and their economic parameters. Its task is to design methodologies for evaluating the effectiveness of investment projects, as well as monitoring deviations in time, material, and volume parameters of the course of investment (Sedliačiková, 2013). Quality controlling is a partial subsystem of corporate controlling and, at the same time, a supporting tool of quality management. It aims to support future-oriented management of minimising the cost of poor quality, optimising quality costs and increasing the quality of processes in order to achieve customer satisfaction with a direct impact on the economy of the enterprise. Personnel controlling focuses on the proactive solution of human resources issues. Its goal is to monitor deviations of personnel indicators from the plan, and its task is to monitor the return on investment in human resources to maximise the benefits of human resources for the company (Potkány \& Babiaková, 2013). Strategic and operational controlling cannot be separated because they form one interconnected system, interact with each other, and complement each other. It is necessary to realise that there is only one controlling, in individual functional areas of corporate management.

Controlling is currently not possible to implement in enterprises without adequate software support, as can be seen from Table 1, which presents a comparison of basic options for software support for controlling in companies.

Table 1 I Comparison of three basic options for controlling software support

\begin{tabular}{|c|c|c|c|}
\hline & MS Excel & $\begin{array}{l}\text { Controlling module } \\
\text { within the basic } \\
\text { corporate IS }\end{array}$ & $\begin{array}{c}\text { Sophisticated controlling IS } \\
\text { based on Business } \\
\text { Intelligence }\end{array}$ \\
\hline $\begin{array}{l}\text { A } \\
\text { D } \\
\text { V } \\
\text { A } \\
\text { N } \\
\text { T } \\
\text { A } \\
\text { G } \\
\text { E } \\
\text { S }\end{array}$ & $\begin{array}{ll}\text { - } & \text { low price } \\
\text { - } & \text { the possibility to } \\
\text { modify the IS with the } \\
\text { own management } \\
\text { and programming } \\
\text { capacities } \\
\text { high intensity of the } \\
\text { learning process }\end{array}$ & $\begin{array}{l}\text { - } \quad \text { online work with data } \\
\text { access rights and } \\
\text { high system security } \\
\text { relatively short time } \\
\text { response even at } \\
\text { more demanding } \\
\text { recalculations }\end{array}$ & $\begin{array}{l}\text { - } \quad \text { online work with data } \\
\text { - } \quad \text { access rights and high } \\
\text { system security } \\
\text { - } \quad \text { short time response even at } \\
\text { more demanding } \\
\text { recalculations } \\
\text { - } \quad \text { simulation of alternative } \\
\text { solutions } \\
\text { simulation of the impacts of } \\
\text { alternative solutions }\end{array}$ \\
\hline $\begin{array}{l}\text { D } \\
\text { I } \\
\text { S } \\
\text { A } \\
\text { D } \\
\text { V } \\
\text { A } \\
\text { N } \\
\text { T } \\
\text { A } \\
\text { G } \\
\text { E } \\
\text { S }\end{array}$ & $\begin{array}{l}\text { - } \quad \text { work with data is only } \\
\text { possible in batches } \\
\text { access rights and low } \\
\text { - } \quad \text { relatively long-time } \\
\text { response at more } \\
\text { demanding } \\
\text { recalculations }\end{array}$ & $\begin{array}{l}\text { - } \quad \text { higher price, } \\
\text { time and money } \\
\text { required to modify the } \\
\text { basic solution } \\
\text { (supplier company) } \\
\text { lower intensity of the } \\
\text { learning process }\end{array}$ & $\begin{array}{l}\text { - } \quad \text { high price, } \\
\text { time and money required to } \\
\text { modify the basic solution } \\
\text { (supplier company) }\end{array}$ \\
\hline
\end{tabular}

Source: Sedliačiková et al. (2019) 
The controlling information system is often referred to in foreign literature as Information System-Controlling (IS-Controlling), which is a subsystem of Information TechnologyControlling (IT-Controlling). IT-Controlling is a combination of controlling and information technology (IT) (Hess, 2007). Current business models or current trends require more intensive support through information technologies, which is associated with a constant increase in procurement costs. However, due to the close integration of business processes and information technologies, it is difficult to find out the added value which the technologies have brought. IS-Controlling is given a central role to support business management. ISControlling plans, guards, and controls the information flow in the company, which includes electronically entered data on costs, sales, etc. (Becker \& Winkelmann, 2004).

\section{Methodology}

The research consisted of four key stages. In the first stage of solution, an analysis of secondary sources was performed through a literature review of domestic and foreign professional and scientific publications, and the concept of the structure and content focus of controlling for SMEs was presented.

In the second stage, an analysis of the current state of use and perception of controlling information systems in MSEs in Slovakia was performed. Empirical research was carried out using the questioning method. The questionnaire was sent to 2,415 MSEs, with the research sample consisting of 421 respondents, i.e. of $17.43 \%$. According to the methodology to determine the minimum sample size, as described below, we can determine the minimum sample size of respondents to maintain the condition of generalisation of results (Kaščáková \& Nedelová, 2014).

$$
n \geq \frac{z^{2} \times p \times(1-p)}{c^{2}}
$$

where:

$\mathrm{n}-$ the minimum required number of respondents,

$\mathrm{z}-$ is the value based on statistical tables (at a confidence level of $95 \%$, the variable is equal to 1.96),

$p$ - character ratio (at unknown values, 0.5 is substituted for $p$ ),

c - acceptable margin of error (in the normal marketing survey, it is set on a scale from $2 \%$ to $10 \%)$. For the needs of economic applications, a significance level of $5 \%(\alpha=0.05)$ is used.

After substituting the appropriate values into the formula, the authors calculated the minimum size of the sample:

$$
n \geq \frac{z^{2} \times p \times(1-p)}{c^{2}} \rightarrow n \geq \frac{1.96^{2} \times 0.5 \times(1-0.5)}{0.05^{2}} \rightarrow n \geq 384
$$

The calculation shows that the sample must consist of at least 384 respondents, i.e. SMEs from SR. As 421 respondents took part in the survey, the results of the survey can be generalised to the whole basic set - the survey meets the condition of a minimum sample size. 
The following hypothesis was defined from the literature review (Becker \& Winkelmann, 2004; Potkány \& Babiaková, 2013; Šatanová \& Sedliačiková, 2014; Stroková \& Drábek, 2018; Sedliačiková et al., 2019):

H1: It is assumed that most MSEs in Slovakia want to use a cost-effective information system to support managerial decisions.

The hypothesis $\mathrm{H} 1$ was tested through a binomial test that the null hypothesis in accordance with the population share. The test replies to the question whether it is possible to claim based on the sample that the share in the basic set is equal to a certain number or another share in the set (or is bigger or smaller than the given number/another calculated share).

In the third stage, based on the analysis of primary and secondary sources, a controlling information system was designed and presented in MS Excel. Various functions of patterning, formatting and hypertext links were used in the creation of the information system, which ensured the 'semaphore' evaluation of individual analyses.

In the final phase, the method of summarisation was applied to evaluate the achieved results and define the benefits for the theory, science and especially for the practice of MSEs.

\section{Results and discussion}

The results of the questionnaire survey showed that up to $84.2 \%$ of Slovak MSEs do not use any information system in their company to support managerial decisions. On the contrary, only $15.8 \%$ of MSEs use the information system. Similar results were obtained by foreign authors Gunther and Schomaker (2012) and Feldbauer-Durstmüller and Hiebl (2015), who found that MSEs use information systems to support managerial decisions to a minimal extent compared to larger enterprises. At the same time, they emphasise that adapting controlling brings them specific benefits (Berens \& Wuller, 2007), for example, argue that MSEs can identify potential threats on time through appropriate strategic controlling, thus avoiding acute crises in their business and reducing their insolvency. Other foreign research (Berens \& Wuller, 2007; Qureshi et al., 2008, 2009) has also identified significant evidence that information technology helps micro-enterprises to operate more efficiently.

The main reason for not using information systems is mainly the financial complexity of their procurement, as stated by $94 \%$ of respondents. The other most common reasons are a resistance of employees (2.5\%), lack of technical equipment $(1.9 \%)$, long implementation process $(1.3 \%)$, and $3 \%$ of respondents indicated the possibility of other. Shpak et al. (2020) consider financial demands and lack of know-how to be the biggest barriers to the implementation of new information systems and innovations. Another major barrier was identified in the study by Qureshi et al. (2008), namely the resistance of employees. Particularly, micro-enterprises are usually managed by one person, who is responsible for the whole operation of the enterprise. That is why it is necessary to adapt the information system so that it does not take the time of the entrepreneur, but on the contrary, helps him to speed up and simplify the work with information.

If there was a financially inexpensive information system to support managerial decisions, it would be used by up to $91.7 \%$ of Slovak MSEs. Despite the financial simplicity of the information system, $5 \%$ of respondents would not use it, and $3.3 \%$ could not express it clearly. 
Hypothesis $\mathrm{H} 1$ was also related to this issue where it was assumed that most MSEs in Slovakia want to use a cost-effective information system to support managerial decisions.

The validity of the hypothesis was verified using the binomial test (Table 2). The results show that the p-level is lower than the selected level of significance of $5 \%$, i.e. the hypothesis was confirmed.

Table 2 I Binomial test results for the hypothesis H1

\begin{tabular}{|c|c|c|c|c|c|c|}
\hline \multicolumn{7}{|c|}{ Binomial Test } \\
\hline \multirow{5}{*}{$\begin{array}{l}\text { Using a financially inexpensive } \\
\text { information system to support } \\
\text { managerial decisions }\end{array}$} & & Category & $\mathrm{N}$ & $\begin{array}{c}\text { Observed } \\
\text { Prop. }\end{array}$ & $\begin{array}{l}\text { Test } \\
\text { Prop. }\end{array}$ & $\begin{array}{c}\mathrm{p}- \\
\text { value }\end{array}$ \\
\hline & yes & 1 & 386 & 0.91687 & 0.5 & 0.000 \\
\hline & no & 0 & 21 & 0.04988 & & \\
\hline & $\begin{array}{l}\text { clearly } \\
\text { express }\end{array}$ & 0 & 14 & 0.03325 & & \\
\hline & Total & & 421 & 1.0000 & & \\
\hline
\end{tabular}

Source: authors' own research

Riemenschneider et al. (2003) conducted similar research on thousands of small enterprises and found that enterprises are ready to overcome most barriers to implementing information technologies. This is because the pressure to keep a competitive position and support customer service is greater than the barriers to the implementation of information systems. In the study, they assumed that MSEs expected that if they could process information faster and more efficiently, be more accessible to customers and have a better overview of their enterprises and the environment, it would mean a gradual growth of existing capacity and a gradual transformation to dynamic and efficient larger national enterprise (Levy et al., 2001; Matthews, 2007; Servon \& Doshna, 2000).

Based on the analysis of primary and secondary sources, it can be stated that for the needs of the application of controlling in micro and small enterprises, one of the most suitable software solutions is the use of MS Excel from MS Office (Sedliačiková et al., 2019; Stroková \& Drábek, 2018;). For this reason, the comprehensive concept of the structure and content focus of controlling for SMEs was transformed into a practical level in the form of a proposal for a controlling information system (CIS) 'SOFIN-KA'. This name consists of the abbreviations of the first letters (in the Slovak language) of the individual controlling subsystems, namely S - strategic, O - operational, F - financial, I - investment, N - cost, K - controlling, A - assistant. The designation controlling assistant was chosen because the system only serves to help the manager. The breakdown of the subsystems is presented in Figure 2. 


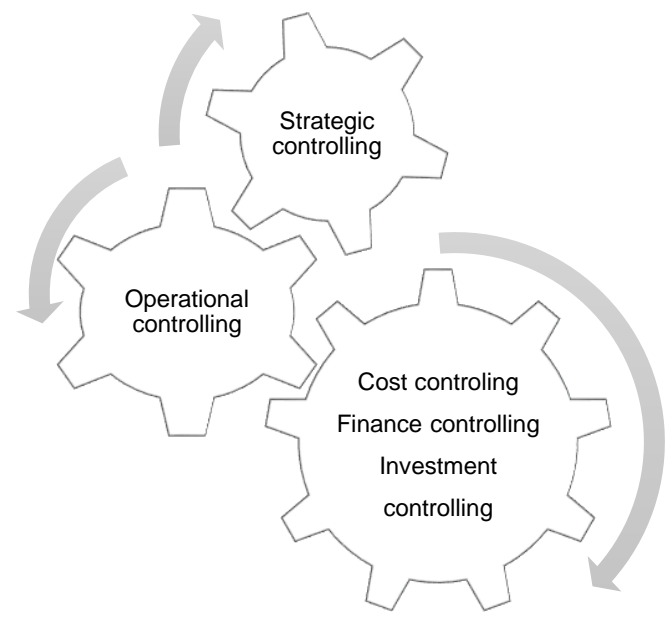

Source: Marková et al. (2017)

The CIS was built based on the following idea: 'Everything in the company works together like interlocking gears. If one of them gets stuck, i.e. does not provide correct, timely, accurate and addressable information, the whole system, i.e. the company stops to function effectively' (Hamáry Gurová \& Sedliačiková, 2016). The system provides output information, the quality of which corresponds to the quality of the input information to the system. After entering Excel, the tab will be displayed, namely the most important subsystems from the proposed concept of corporate controlling for MSEs. By clicking on the module, e.g. financial controlling, another tab will open presenting the financial controlling activities. For the system to work, it is necessary to fill in the input data from the balance sheet and profit and loss statement. This software support is based on 'semaphore' business management and allows MSEs to respond flexibly to market changes and offers alternative solutions without managers having to spend hours on complex calculations and spreadsheets. It can also simulate the effects of any change in the plan on business management, and the company can quickly respond to operational and strategic management and adapt plans to new market conditions. The data entered in the input forms affect the number of analyses and always at least a pair of subsystems, which are again affected by other subsystems (the principle of interlocking gears). The whole CIS is based on moving through various hyperlinks, through which the user can easily move. The areas in which the user can enter data to perform the necessary analyses or model potentially possible situations are the cells in diverse colours. The CIS also allows the user to perform analyses on their competitors, up to the level where they have the necessary input data on the counterparty, which they can obtain from various publicly available registers (e.g. the register of financial statements, FINSTAT and others). Also, selected indicators and analyses are supplemented by notes that bring the user closer to the interpretation of the results (Marková et al., 2017). A breakdown of the maximum package of analyses and methods that can be performed within the individual subsystems that 'SOFINKA' offers as a comprehensive CIS is shown in Table 3. 
Table 3 I Breakdown of analyses in individual dimensions

\begin{tabular}{|c|c|c|c|c|c|}
\hline \multicolumn{6}{|c|}{ Controlling } \\
\hline \multicolumn{6}{|c|}{ Strategic controlling } \\
\hline \multicolumn{3}{|c|}{ Experience cost curve } & \multicolumn{3}{|c|}{ SWOT analysis } \\
\hline \multicolumn{3}{|c|}{ Environmental analysis } & \multicolumn{3}{|c|}{ GAP analysis } \\
\hline \multicolumn{3}{|c|}{ Strategic synthesis } & \multicolumn{3}{|c|}{ BCG matrix } \\
\hline \multicolumn{6}{|c|}{ Operational controlling } \\
\hline Financial ste & ments plan & \multicolumn{2}{|c|}{ Financial plan } & \multicolumn{2}{|c|}{ Purchase plan } \\
\hline $\begin{array}{r}\text { Sale } \\
\text { Cash flow }\end{array}$ & $\begin{array}{l}\text { blan } \\
\text { tatement }\end{array}$ & \multicolumn{2}{|c|}{ Investment plan } & \multicolumn{2}{|c|}{ Production plan } \\
\hline \multicolumn{2}{|c|}{ Financial controlling } & $\begin{array}{c}\text { Cost } \\
\text { controlling }\end{array}$ & \multicolumn{3}{|c|}{ Investment controlling } \\
\hline $\begin{array}{c}\text { Financial } \\
\text { planning and } \\
\text { financial } \\
\text { analysis }\end{array}$ & $\begin{array}{l}\text { Controlling } \\
\text { short-term } \\
\text { surpluses }\end{array}$ & $\begin{array}{c}\text { Level } 1 \text { cost } \\
\text { analysis }\end{array}$ & $\begin{array}{l}\text { Dynamic } \\
\text { methods }\end{array}$ & $\begin{array}{c}\text { Profit } \\
\text { comparison }\end{array}$ & $\begin{array}{l}\text { Profitability } \\
\text { index }\end{array}$ \\
\hline $\begin{array}{l}\text { Financial } \\
\text { control }\end{array}$ & $\begin{array}{l}\text { Working } \\
\text { capital } \\
\text { controlling }\end{array}$ & $\begin{array}{c}\text { Level } 2 \text { cost } \\
\text { analysis }\end{array}$ & $\begin{array}{l}\text { Statical } \\
\text { methods }\end{array}$ & $\begin{array}{l}\text { Net present } \\
\text { value }\end{array}$ & $\begin{array}{c}\text { Modified } \\
\text { internal rate of } \\
\text { return }\end{array}$ \\
\hline $\begin{array}{l}\text { Valuation of } \\
\text { the enterprise }\end{array}$ & $\begin{array}{l}\text { Controlling of } \\
\text { ongoing } \\
\text { liquidity }\end{array}$ & Cost indicators & $\begin{array}{c}\text { Cost } \\
\text { comparison }\end{array}$ & $\begin{array}{l}\text { Internal rate of } \\
\text { return }\end{array}$ & Discounted \\
\hline $\begin{array}{c}\text { Mod. methods } \\
\text { of measuring } \\
\text { business } \\
\text { performance }\end{array}$ & $\begin{array}{c}\text { Controlling } \\
\text { short-term } \\
\text { deficits }\end{array}$ & Budgeting & $\begin{array}{c}\text { Comparison } \\
\text { of } \\
\text { profitability }\end{array}$ & $\begin{array}{l}\text { Payback } \\
\text { period }\end{array}$ & payback period \\
\hline
\end{tabular}

Source: authors' own research

As can be seen from Table 3, the dominant area of the whole system is financial controlling, as this area is key to the everyday decision-making of MSEs managers (Sedliačiková et al., 2019; Stroková \& Drábek, 2018). As stated by Beck \& Demirguc-Kunt (2006) and Ropega (2011), one of the shortcomings of the management of MSEs is that they are interested in this area only in selected situations and do not pay importance to it. Following financial stability, according to Reichmann (2010), the main task of financial management, and thus of financial controlling, is to ensure liquidity. Maintaining this constant payment readiness and the financial balance shall be respected regarding the profitability objectives.

In the proposed CIS 'SOFIN-KA', the main task of the subsystem is strategic controlling, so that the user can identify his position on the market and possibly find out according to the incorporated methodology which strategy would be most suitable for his company. These analyses can only be performed provided that the user has the relevant input data.

Since the orientation of operational controlling is for less than one year, this subsystem is usable daily for the owners and managers of MSEs, because it is possible to create quarterly or monthly plans. In the structure of the operational controlling subsystem, forms such as the planned balance sheet and the planned profit and loss statement (or in the case of simple accounting - the planned statement of assets and liabilities, the income statement) play the most important role. As the authors Šatanová and Sedliačiková (2014) and Hamáry Gurová \& Sedliačiková (2016) agree, the currently planned balance sheet and the planned profit and loss statement are the basis from which the primary plan (sales plan) and other secondary 
plans are derived, such as purchase plan, inventory plan, production plan, investment plan, etc. They also affect other parts of the whole system.

Innovative business intentions require careful planning and evaluation of efficiency and profitability. For this purpose, the investment controlling subsystem is located in CIS 'SOFINKA'. As stated by Šatanová and Sedliačiková (2014), to evaluate the economic efficiency of investments, it is necessary to use static but especially dynamic methods of evaluation of investment projects. These methods were incorporated into the CIS (Table 3).

Cost controlling subsystem includes a deeper analysis of cost and for its needs requires to be linked with the accounting IS, respectively regular updating of the form with input data.

CIS 'SOFIN-KA' was successfully tested and installed in several Slovak micro and small enterprises. In practice, it has been confirmed that it is an affordable, relatively simple and effective tool for creating optimal and flexible managerial decisions, and it can be tailored for each MSEs.

\section{Conclusion}

Micro and small enterprises present an important segment not only in emerging economies. The flexibility and competitiveness of the European economy depend on their prosperity and financial health. In today's turbulent business environment, managers need to be able to make quick and effective decisions and to do so; they need an efficient, fast, and effective management information system.

The effort of every enterprise is to have such an information system that allows it to determine the best way to set goals without long-term analysis and recalculations. Making better and faster decisions means working more efficiently, increasing competitiveness and developing further. And so, information technology and information system have become a very important helper for companies to support managerial decisions. Information systems provide high analytical comfort and easy access to clearly collected data. Currently, there are various information systems that, after entering the necessary data, could relieve the manager of several tasks. It is possible to define three basic variants of the environment for the software support of controlling (Nelles, 2011): based on MS Excel, as a Controlling module within the basic information systems of the company and through information system based on Business Intelligence, which works as a managerial superstructure of the basic information system. The achieved results of empirical research in the environment of MSEs in Slovakia clearly showed that due to financial demands, this group of enterprises could not afford to implement software support for controlling based on Business Intelligence or based on the Controlling module within the basic information system of the company. Thus, in terms of affordability and relative simplicity of the solution, the implementation of software support for controlling based on the MS Excel programme was identified as the most suitable alternative for MSEs. More than $90 \%$ of all Slovak MSEs wants to use an information system in this programme. Due to the requirements of practice, the CIS 'SOFIN-KA' was created in the MS Excel programme. The unique information system 'SOFIN-KA' represents the maximum possible package of offered methods and analyses that the given system provides. However, this information system is adaptable to the needs of each MSEs based on individual requirements. Controlling information system is based on the principle of interlocking gears, which represent the interconnection of individual controlling subsystems. It is programmed 
based on 'semaphore' management, which informs the manager whether the company is in green or red numbers. The information system also offers explanations of the individual values of the calculated indicators. Financial controlling is the dominant subsystem of an information system because it is necessary for MSEs in terms of the daily decisions of managers. Controlling information system enables MSEs managers to make real-time optimal managerial decisions in individual functional areas of business management.

The research had several fundamental limitations that need to be mentioned. One of them was that the proposed CIS 'SOFIN-KA' was tested only in micro and small enterprises in Slovakia. Another limitation of the research is that it will be necessary to carry out training so that managers can learn to effectively operate with the proposed information system. This means that additional funds will have to be spent on the implementation of the information system. As medium-sized enterprises form a crucial part of the economic potential of emerging economies, the goal of future research will be to transform the proposed CIS 'SOFIN-KA' into this segment of enterprises as well. The achieved research results make it possible to formulate conclusions that expand current knowledge in the field of research.

\section{Acknowledgement}

The paper has been written as a partial result of the projects APVV-18-0520, APVV-18-0378, APVV-17-0456, APVV-17-0583, APVV-20-0004 and VEGA 1/0161/21.

\section{References}

Beck, T., \& Demirguc-Kunt, A. (2006). Small and medium-size enterprises: Access to finance as a growth constraint. Journal of Banking \& Finance, 30(11), 2931-2943. https://doi.org/10.1016/j.jbankfin.2006.05.009

Becker, J., \& Winkelmann, A. (2004). IV-Controlling. Wirtschaftsinformatik, 46(3), 213-221. https://doi.org/10.1007/BF03250939

Berens, W., \& Wuller, F. (2007). Strategisches Controlling in KMU: Bedeutung, Umsetzungsstand und edv-technische Unterstutzung. Controlling, 19(7), 393-404.

Bernardová, D., Kašparová, K., Fink, M., Ivanová, K., \& Arkhangelska, T. (2020). Construction and significance of corporate social responsibility indices - From results to the essence. Organizacija, 53(3), 212-226. https://doi.org/10.2478/orga-2020-0014

Claussen, H. (2003). Instrumente für das Finanzcontrolling. Controlling NEWS, 2, 17-18.

Deming, D. J. (2017). The growing importance of social skills in the labor market. Quarterly Journal of Economics, 132, 1593-1640.

Dvorský, J., Kozubíková, I., \& Bacová, B. (2020). The perception of business risks by SMEs in the Czech Republic. Central European Business Review, 9(5), 25-44. https://doi.org/10.18267/j.cebr.250

Feldbauer-Durstmüller, B., \& Hiebl, M. R. W. (2015). Aktuelle Trends und Entwicklungen im Controlling in und für KMU: Eine Einführung der Gastherausgeber. ZfKE - Zeitschrift für KMU und Entrepreneurship, 63(3-4), 193-208.

Fickert, R., Geuppert, F., \& Künzle, A. (2003). Finanzcontrolling. Verlag.

Fischer, T. M., Möller, K., \& Schultze, W. (2012). Controlling - Crundlagen Instrumente, Perspektiven. Verlag.

Foltínová, A. (1997). Finančný controlling podniku. Finančný poradca podnikatela, 2(3), 33-50. 
Gunther, T., \& Schomaker, M. (2012). 10 Thesen für mehr Effizienz in der Planung mittelständischer Unternehmen. Zeitschrift fur Controlling \& Management, 56(3), 18-30.

Hajdúchová, I., Giertliová, B., \& Šulek, R. (2017). Specifics of forest enterprises' performance measurement. Austrian Journal of Forest Science, (2017), 23-40.

Hamáry Gurová, D., \& Sedliačiková, M. (2016). How to improve managerial decisions in micro and small enterprises. Economy, finance and business management, $X, 143-152$.

Hess, T. (2007). IT-Controlling: Eine separate Welt. Controlling \& Management, 51(4), 225-225. https://doi.org/10.1007/s12176-007-0062-4

Hitka, M., Hajdukova, A., \& Balazova, Z. (2014). Impact of economic crisis on changes in motivation of employees in woodworking industry. Drvna Industrija, 65(1), 21-26.

Chaudhuri, S., Dayal, U., \& Narasayya, V. (2011). An overview of business intelligence technology. Communications of the ACM Magazine, 54(8), 88-98. https://doi.org/10.1145/1978542.1978562

Jerman, A., Bertoncelj, A., Dominici, G., Pejić Bach, M., \& Trnavčević, A. (2020). Conceptual key competency mode for smart factories in production processes. Organizacija, 53(1), 68-79. https://doi.org/10.2478/orga-2020-0005

Kaščáková, A., \& Nedelová, G. (2014). Dotazníkový prieskum II. - overovanie hypotéz. Forum Statisticum Slovacum: vedecký recenzovaný časopis Slovenskej štatistickej a demografickej spoločnosti, 10, 109-114.

Krause, H. U., \& Dayanand, A. (2010). Controlling-Kennzahlen - Key Performance Indicators. Oldenbourg Wissenschaftsverlag.

Lesnikova, P., \& Schmidtova, J. (2020). Development of corporate sustainability in enterprises through the application of selected practices and tools. Organizacija, 53(2), 112-126. https://doi.org/10.2478/orga-2020-0008

Levy, M., Powell, P., \& Yetton, P. (2001). SMEs: Aligning IS and the strategic context. Journal of Information Technology, 16(3), 133-144.

Marceta, M., \& Bojnec, S. (2020). Drivers of global competitiveness in the European Union countries in 2014 and 2017. Organizacija, 53(1), 37-52. https://doi.org/10.2478/orga-2020-0003

Marková, V., Sedliačiková, M., \& Hamáry Gurová, D. (2017). Controlling - input versus output. In S. Rojík \& J. Závodný Pospíšil (Eds.), Proceedings of 9th annual international scientific conference COMPETITION (pp. 44-52). College of Polytechnics Jihlava.

Matthews, P. (2007). ICT Assimilation and SME expansion. Journal of International Development, 19(1007), 817-927.

Nelles, S. (2011). Excell 2010 im Controlling. Das umfassende Handbuch. Gallileo Press.

Peréz-Nordtvedt, L., Kedia, B. L., Datta, D. K., \& Rasheed, A. A. (2008). Effectiveness and efficiency of cross border knowledge transfer: An empirical examination. Journal of Management Studies, 45(4), 714-744. https://doi.org/10.1111/j.1467-6486.2008.00767.x

Potkány, M., \& Babiaková, M. (2013). Management of support processes by means of controlling. In S. Borkowski \& T. Grladinović (Eds.), Toyotarity. Management of the Production Values (pp. 6072). Savas Kitap ve Yaymevi.

Qureshi, S., Kamal, M., \& Wolcott, P. (2008). Sustainability of information technology therapy on microenterprise development. Proceedings of the 41st Annual Hawaii International Conference on System Sciences (HICSS 2008, pp. 409-409). https://doi.org/10.1109/HICSS.2008.419 
Qureshi, S., Kamal, M., \& Wolcott, P. (2009). Information technology interventions for growth and competitiveness in micro-enterprises. International Journal of E-Business Research, 5(1), 117140.

Ratinger, T., Čadil, V., \& Agyemang, S. A. (2020). Are there any economic impacts of business R\&D support? The case of the Czech Republic. Central European Business Review, 9(5), 45-62. https://doi.org/10.18267/j.cebr.251

Reichmann, T. (2010). Controlling mit Kennzahlen und Management-Tools: Die systemgestützte Controlling-Konzeption. Vahlen.

Riemenschneider, C. K., Harrison, D. A., \& Mykytyn, P. P. (2003). Understanding it adoption decisions in small business: Integrating current theories. Information \& Management, 40(4), 269-285.

Ropega, J. (2011). The Reasons and symptoms of failure in SME. International Advances in Economic Research, 17(4), 476-483. https://doi.org/10.1007/s11294-011-9316-1

SBA Fact Sheet Slovakia. (2018). Správa o stave malého a stredného podnikania v Slovenskej republike v roku 2017. http://www.sbagency.sk/

Sedliačiková, M. (2013). Evaluation of economic efficiency of the investment project through controlling's methods. Annals of Warsaw University of Life Sciences. Forestry and Wood Technology, 84, 153-158.

Sedliačiková, M., Hajdúchová, I., Krištofík, P., Viszlai, I., \& Gaff, M. (2016). Improving the performance of small and medium wood-processing enterprises. Bioresources, 11(1), 439-450. https://doi.org/10.15376/biores.11.1.439-450

Sedliačiková, M., Stroková, Z., Drábek, J., \& Malá, D. (2019). Controlling implementation: What are the benefits and barriers for employees of wood processing enterprises? Acta Facultatis Xylologiae, 61(2), 163-173. https://doi.org/10.17423/afx.2019.61.2.15

Sedliačiková, M., Šatanová, A., \& Foltínová, A. (2012). Finančný kontroling v teórii a praxi malých a stredných podnikov. Ekonomický časopis/Journal of economic, 60(9), 949-966.

Sedliacikova, M., Vacek, V., \& Sopkova, E. (2015). How Slovak small and medium enterprises perceive financial controlling. Procedia Economics and Finance, 26, 82-85. https://doi.org/10.1016/S2212-5671(15)00842-4

Servon, L. J., \& Doshna, J. P. (2000). Microenterprise and the economic development toolkit: A small part of the big picture. Journal of Developmental Enterpreneurship, 5(3), 183.

Shpak, N., Naychuk-Khrushch, M. B., Kohut, U., Honchar, M., \& Sroka, W. (2020). The usage of modern instruments of business planning administration for small enterprises: A case study analysis. Central European Business Review, 9(1), 20-42. https://doi.org/10.18267/j.cebr.227

Szalavetz, A. (2019). Artificial intelligence-based development strategy in dependent market economies - Any room amidst big power rivalry? Central European Business Review, 8(4), 40-54. https://doi.org/10.18267/j.cebr.219

Stroková, Z., \& Drábek, J. (2018). Financing preferences and practices of SMEs in wood processing and furniture industry in Slovakia. In B. Glavonjic (Ed.), Increasing the use of wood in the global bioeconomy. Proceedings of scientific papers (pp. 130-137). University of Belgrade. http://www.woodema.org/proceedings/WoodEMA_2018_Proceedings.pdf

Šatanová, A., \& Sedliačiková, M. (2014). Quality controlling for small and medium-size enterprises. Annals of Warsaw University of Life Sciences, 85, 211-220. 
Vetráková, M., Hitka, M., Potkány, M., Lorincová, S., \& Smerek, L. (2018). Corporate sustainability in the process of employee recruitment through social networks in conditions of Slovak small and medium enterprises. Sustainability, 10(5), 1670. https://doi.org/10.3390/su10051670

Vrchota, J., Vlckova, M., \& Frantikova, Z. (2020). Division of enterprises and their management strategies in relation to industry 4.0. Central European Business Review, 9(4), 27-44. https://doi.org/10.18267/j.cebr.243

The research article passed the review process. | Received: April 23, 2021; Revised: June 8, 2021; Accepted: June 25, 2021; Pre-published online: October 31, 2021; Published in the regular issue: December 6, 2021. 